\title{
Effect of deforestation and subsequent land use management on soil carbon stocks in the South American Chaco
}

\author{
Natalia Andrea Osinaga ${ }^{1}$, Carina Rosa Álvarez ${ }^{2}$, and Miguel Angel Taboada ${ }^{1,2,3}$ \\ ${ }^{1}$ CONICET, National Council of Scientific and Technical Research, \\ Ciudad Autónoma de Buenos Aires, Argentina \\ ${ }^{2}$ University of Buenos Aires, School of Agronomy, Soil Fertility and Fertilizer, \\ Av. San Martín 4453, Ciudad Autónoma de Buenos Aires, 1417, Argentina \\ ${ }^{3}$ Soil Institute, CIRN, INTA, Hurlingham, Buenos Aires, Argentina \\ Correspondence: Carina Rosa Álvarez (alvarezc@agro.uba.ar)
}

Received: 5 December 2017 - Discussion started: 12 April 2018

Revised: 26 September 2018 - Accepted: 6 October 2018 - Published: 1 November 2018

\begin{abstract}
The subhumid Chaco region of Argentina, originally covered by dry sclerophyll forest, has been subjected to clearing since the end of the 1970s and replacement of the forest by no-till farming. Land use changes produced a decrease in aboveground carbon (C) stored in forests, but little is known about the impact on soil organic $\mathrm{C}$ stocks. The aim of this study was to evaluate soil $\mathrm{C}$ stocks and $\mathrm{C}$ fractions up to $1 \mathrm{~m}$ depth in soils under different land use: < 10-year continuous cropping, > 20-year continuous cropping, warm-season grass pasture and native forest in 32 sites distributed over the Chaco region. The organic $\mathrm{C}$ stock content up to $1 \mathrm{~m}$ depth expressed as equivalent mass varied as follows: forest $\left(119.3 \mathrm{Mg} \mathrm{ha}^{-1}\right)>$ pasture $\left(87.9 \mathrm{Mg} \mathrm{ha}^{-1}\right)>$ continuous cropping ( 71.9 and $77.3 \mathrm{Mg} \mathrm{ha}^{-1}$ ), with no impact of the number of years under cropping. The coarse particle fraction $(2000-212 \mu \mathrm{m})$ at $0-5$ and 5-20 $\mathrm{cm}$ depth layers was the most sensitive organic carbon fraction to land use change. Resistant carbon $(<53 \mu \mathrm{m})$ was the main organic matter fraction in all sample categories except in the forest. Organic $\mathrm{C}$ stock, its quality and its distribution in the profile were responsive to land use change. The conversion of the Chaco forest to crops was associated with a decrease of organic $\mathrm{C}$ stock up to $1 \mathrm{~m}$ depth and with the decrease of the labile fraction. The permanent pastures of warm-season grasses allowed higher $\mathrm{C}$ stocks to be sustained than cropping systems and so could be considered a sustainable land use system in terms of soil C preservation. As soil organic $\mathrm{C}$ losses were not restricted to the first few centimetres of the soil, the development of models that would allow the estimation of soil organic $\mathrm{C}$ changes in depth would be useful to evaluate the impact of land use change on $\mathrm{C}$ stocks with greater precision.
\end{abstract}

\section{Introduction}

As one of the components of global change, land use change has a great impact on terrestrial ecosystems, altering their structure and function (Walker and Steffen, 1999). The most important land use change is due to agriculturisation (Houghton, 1999), a process that involves replacement of natural ecosystems, such as forests, by agricultural land (cropping or grassland systems) as world food demand increases (Volante et al., 2012).
In Argentina, since the late 1970s, there has been an advance of the agricultural frontier across the Chaco region native forests due to conversion for production of annual crops (Gasparri et al., 2009). Thus, it became one of the 10 countries with the greatest forest loss in the world (FAO, 2015). The eastern subhumid Chaco is a large forest area that since 1997 has suffered a notable increase in forest-cleared area (Albanesi et al., 2003; Grau et al., 2005; Volante et al., 2009). The average deforestation rate is among the highest in the world and in the country, mainly in the east of the province 
of Santiago del Estero, where Mollisols are the predominant soil type (Volante et al., 2009).

Deforestation together with inadequate subsequent management leads to acceleration of erosive processes, reduction of organic matter input, decrease of soil aggregate stability (Cerdà, 2000; Cerdà et al., 2009; García Orenes et al., 2010), changes in microclimate and biodiversity loss, affects water basin functions and contributes to global climate warming. These effects have been studied mostly in tropical and temperate forests but have been poorly evaluated in South American subtropical forests (Baccini et al., 2012; Harris et al., 2012; Hansen et al., 2013).

In the subhumid Chaco, the intensity and seasonality of rainfall, the gently undulating landscape, the fragility of the environment and the subtropical climate predispose the soil to substantial physical degradation (Albanesi et al., 2003). No-tillage was introduced in Argentina, including in the Chaco region, in the mid-1990s. It was adopted due to its lower production costs, the possibility it offered of incorporating areas with greater limitations to crop yield (Satorre, 2005; Derpsch et al., 2010), to savings in operating time and to lack of soil disturbance that reduces soil erosion, recovers soil aggregate stability, conserves water and increases carbon sequestration in the first few centimetres of soil (Díaz Zorita et al., 2002). Despite its many advantages, no-tillage can negatively impact some physical properties of the surface soil (bulk density, penetration resistance), as mechanical formation of macropores is reduced and there is a tendency to form laminar and massive structures (Strudley et al., 2008; Álvarez et al., 2009, 2012). All these effects are increased by the transit of heavy machinery that produces soil compaction of the first 40 centimetres of soil, especially when the soil is wet (Botta et al., 2004).

In the western part of the region, livestock production became important, replacing native forests by megathermic pastures. This activity has negative effects on soil physical properties and produces reduction of soil organic carbon levels due to forest clearance and soil compaction caused by animal transit (Caruso et al., 2012). However, it could have a smaller negative impact than continuous agriculture on carbon sequestration and on soil physical properties as animal trampling effects extend to a lesser depth and live roots are present in the soil all year long.

The objective of the present study was to determine carbon stocks and soil physical quality of subhumid Chaco soils under different land uses: agriculture (less than 10 years and more than 20 years under cropping), pastures and natural forests.

\section{Materials and methods}

The region of the subhumid Chaco is part of the Great American Chaco and occupies the southern fringe of the eastern part of the semi-arid Chaco (Vargas Gil, 1988, Fig. 1). In Ar-

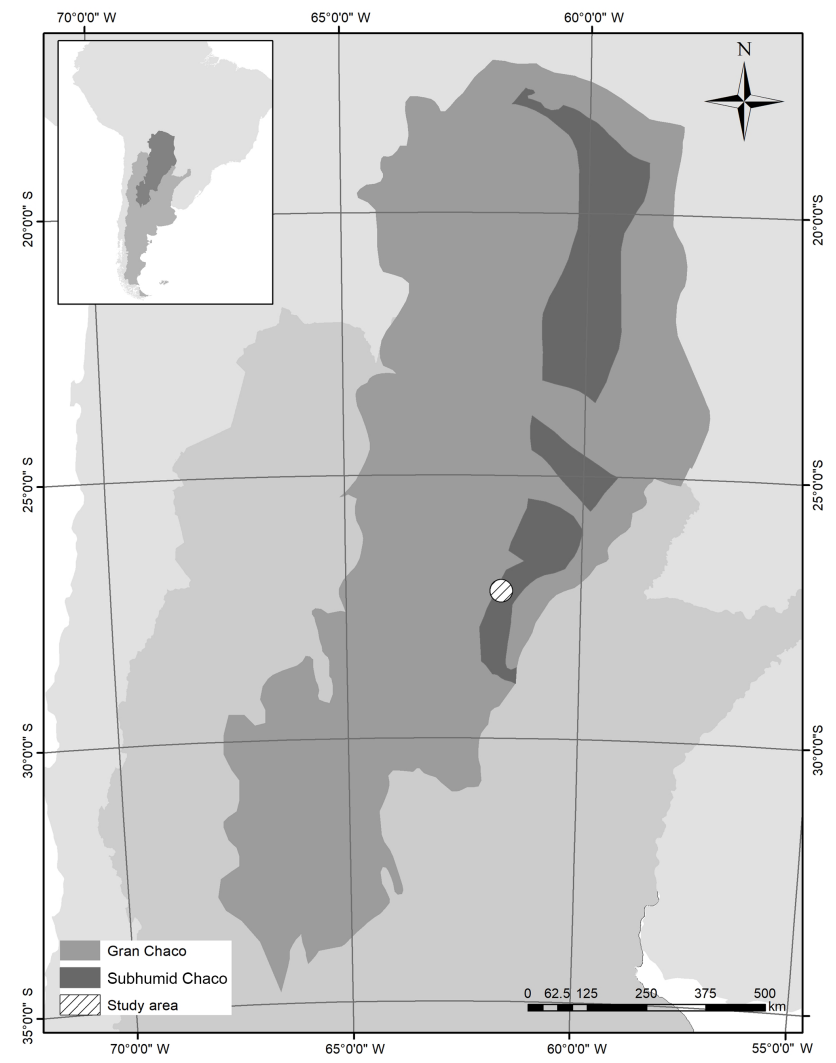

Figure 1. Location of the Gran Chaco, the subhumid Chaco and the study area.

gentina, it covers an area of $45199.33 \mathrm{~km}^{2}$. Annual rainfall ranges from $700 \mathrm{~mm}$ in the west to $1000 \mathrm{~mm}$ on the limit with the humid Chaco (east) and it has a monsoon regime, with periods of marked water deficit during the winter months and the beginning of spring.

The average annual temperature is $21^{\circ} \mathrm{C}$. The most representative soils are Haplustolls and Argiustolls (Vargas Gil, 1988). Crop production is mainly summer crops (soybean, corn, sorghum and cotton) sown in December and January, with winter months generally as fallow periods, in order to store soil water for the summer crop. In the west of the region, livestock production on megathermic pastures predominates. The natural vegetation is a xerophytic forest with dominance of various species of Schinopsis, Prosopis nigra and Ziziphus mistol and shrubs of the genus Acacia.

A total of 32 sites were selected in an area of 320000 ha to the east of the Santiago del Estero province (Fig. 1), which were representative of the most common forms of land use of this region: native forest (reference), continuous cropping (rotation of soybean-soybean-corn under no-till farming) during different periods (6-9 and $>20$ years) and more than 10-year old pastures (pasture, Gatton panic, Panicum maximum) on the most representative soils (typical Haplustolls and Argiustolls) with silty and clayey texture (Table 1). 
Table 1. Main characteristics of the soils of the study region.

\begin{tabular}{lclrrrr}
\hline & $\begin{array}{r}\text { Area } \\
(\%)\end{array}$ & Horizon & $\begin{array}{r}\text { Clay } \\
\left(\mathrm{g} \mathrm{kg}^{-1}\right)\end{array}$ & $\begin{array}{r}\text { Silt } \\
\left(\mathrm{g} \mathrm{kg}^{-1}\right)\end{array}$ & $\begin{array}{r}\text { Sand } \\
\left(\mathrm{g} \mathrm{kg}^{-1}\right)\end{array}$ & $\mathrm{pH}$ \\
\hline Typic Haplustoll & 80 & A & 200 & 430 & 370 & 6.6 \\
& & AC & 350 & 470 & 180 & 6.7 \\
Typic Argiustoll & 20 & A & 250 & 470 & 280 & 6.8 \\
& & Bt & 410 & 400 & 190 & 6.6 \\
\hline
\end{tabular}

Table 2. Mean values and standard errors of soil particle size distribution in the $0-20 \mathrm{~cm}$ layer for different land uses.

\begin{tabular}{lrrr}
\hline Land use & $\begin{array}{r}\text { Clay } \\
\left(\mathrm{g} \mathrm{kg}^{-1}\right)\end{array}$ & $\begin{array}{r}\text { Silt } \\
\left(\mathrm{g} \mathrm{kg}^{-1}\right)\end{array}$ & $\begin{array}{r}\text { Sand } \\
\left(\mathrm{g} \mathrm{kg}^{-1}\right)\end{array}$ \\
\hline Forest & $240 \pm 11.1$ & $400 \pm 13.0$ & $360 \pm 12.4$ \\
Pasture & $240 \pm 15.8$ & $390 \pm 26.2$ & $370 \pm 28.1$ \\
Cropped 6-9 years & $290 \pm 39.3$ & $430 \pm 25.5$ & $280 \pm 44.1$ \\
Cropped > 20 years & $300 \pm 22.4$ & $440 \pm 47.7$ & $260 \pm 52.1$ \\
All land uses & $270 \pm 37.7$ & $410 \pm 34.5$ & $320 \pm 60.1$ \\
\hline
\end{tabular}

From each category, eight sites $(n=8)$ located in different farms were sampled. Mean values and standard errors of soil particle size distribution in the $0-20 \mathrm{~cm}$ layer for different land uses are presented in Table 2.

In each site, a composite sample built up of four subsamples was taken up to $1 \mathrm{~m}$ depth from the $0-5 \mathrm{~cm}$ layer, the 5$20 \mathrm{~cm}$ layer and then every $20 \mathrm{~cm}$. Soil organic carbon (SOC) was determined by wet combustion using the Walkley-Black method (Nelson and Sommers, 1996). Coarse particulate organic carbon (2000-212 $\mu \mathrm{m}, \mathrm{CPC})$, fine particulate organic carbon $(212-53 \mu \mathrm{m}, \mathrm{FPC})$ and resistant organic carbon $(<$ $53 \mu \mathrm{m}, \mathrm{RC}$ ) were determined (Cambardela and Elliot, 1992). Bulk density (BD) was determined using the cylinder method (Burke et al., 1986) with $100 \mathrm{~cm}^{3}$ cylinders. Carbon content mass per unit area was estimated using sample BD values. To compare soil total organic carbon stocks $\left(\mathrm{Mg} \mathrm{ha}^{-1}\right)$ a correction was made to bring soil profiles to mass-equivalence up to $1 \mathrm{~m}$ depth (Neill et al., 1997).

Additionally, four soil subsamples from the $0-20 \mathrm{~cm}$ layer were taken in each site to determine the structural stability according to the methodology described by Le Bissonnais (1996). Aggregates of 3 to $5 \mathrm{~mm}$ in diameter were dried at $40^{\circ} \mathrm{C}$ for $24 \mathrm{~h}$ and then subjected to three pretreatments: fast wetting of air-dry aggregates with distilled water, wet agitation (previously treated with ethanol) and low wetting (capillarity with distilled water). After applying these pretreatments, the distribution of the aggregates according to their size was determined using a series of sieves $(0.05,0.1$, $0.2,0.5,1$ and $2 \mathrm{~mm}$ ). The aggregate mean weight diameter (MWD) for each pretreatment was calculated as an index of the structural stability obtained as the algebraic sum of the percentage of the total mass of soil retained in each sieve, multiplied by the opening of the adjacent sieves. The MWD for each of the three pretreatments was estimated, and an integrated value of MWD was also calculated. Penetration resistance was determined every 5 up to $40 \mathrm{~cm}$ depth with a $30^{\circ}$ conical tip dynamic penetrometer (Burke et al., 1986), taking four determinations per site. At the same time soil water content (SWC) was determined at two depths (0-20 and 20$40 \mathrm{~cm}$ ), as penetration resistance varies with it. As soil water content was only determined for the $0-20$ and $20-40 \mathrm{~cm}$ layers, the relationship between soil penetration resistance and water content was constructed by integrating soil penetration resistance data for 0 to 20 and 20 to $40 \mathrm{~cm}$ layer depths. We measured MWD and penetration resistance as erosion and compaction are the main soil degradation processes in the studied region. The soil MWD index is conversely related to soil susceptibility to erosion, and soil penetration resistance allows soil compaction derived from machinery transit and animal trampling to be characterised.

Significance of differences was tested using analysis of variance (ANOVA) after checking data normality (ShapiroWilks test) and variance homogeneity.

\section{Results and discussion}

SOC was affected by land use up to a depth of $1 \mathrm{~m}$ (Table 3 ). As land use produces changes in BD (Table 3), SOC content data have been corrected by BD. Mean SOC content up to $1 \mathrm{~m}$ decreased as follows: forest, pasture and cropped fields. The organic $\mathrm{C}$ stock content up to $1 \mathrm{~m}$ depth expressed as equivalent mass showed the same tendency: forest $\left(119.3 \mathrm{Mg} \mathrm{ha}^{-1}\right)>$ pasture $\left(87.9 \mathrm{Mg} \mathrm{ha}^{-1}\right)>$ continuous cropping (71.9 and $77.3 \mathrm{Mgha}^{-1}$ ), with no impact of the number of years under cropping. There was a significant reduction in SOC in the cropped sites compared to the forest in the first $20 \mathrm{~cm}$ and from 40 to $80 \mathrm{~cm}$ depth, while pastures showed this decrease only in the surface layer. Between $34 \%$ and $48 \%$ of SOC was found in the first $20 \mathrm{~cm}$, while in the forest it presented greater stratification. SOC vertical distribution tends to follow the distribution of the root system (Jobbágy and Jackson, 2000); the reason why pastures have a higher SOC is that roots are abundant down to a depth of $80-100 \mathrm{~cm}$.

SOC content depended on the input of carbon contributed by the vegetation that varied among vegetation types. For- 


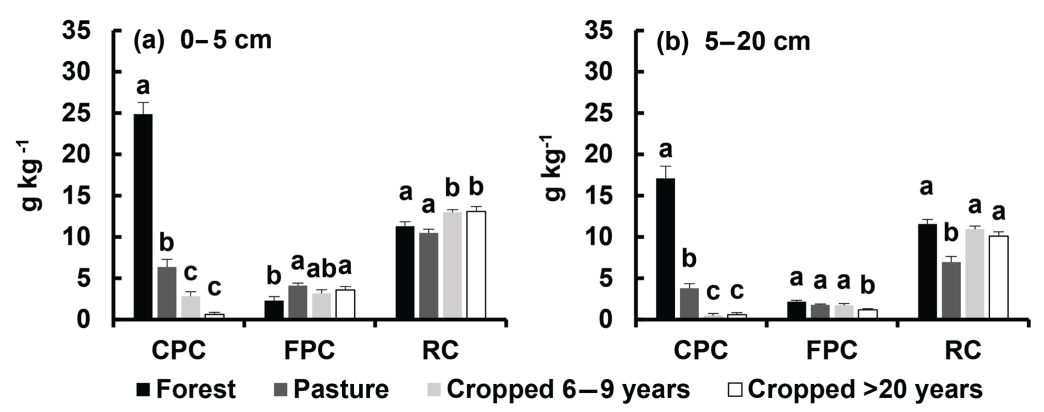

Figure 2. Variation of coarse particulate carbon (2000-212 $\mu \mathrm{m}, \mathrm{CPC})$, fine particulate carbon $(212-53 \mu \mathrm{m}$, FPC) and resistant organic carbon $(<53 \mu \mathrm{m}, \mathrm{RC})$ associated with land use. (a) Depth 0-5 cm. (b) Depth 5-20 cm. Different letters indicate significant differences between land use categories within each depth interval $(P<0.05)$.

Table 3. Soil organic carbon (SOC) and bulk density (BD) variation in depth associated with land use: forest, pasture, 6-9-year and $>20$-year cropped soils. Different letters indicate significant differences between land use categories within each depth layer.

\begin{tabular}{|c|c|c|c|c|c|c|c|c|}
\hline \multicolumn{9}{|c|}{$\operatorname{SOC}\left(\mathrm{Mg} \mathrm{ha}^{-1}\right)$} \\
\hline \multirow[t]{2}{*}{ Depth $(\mathrm{cm})$} & \multirow{2}{*}{\multicolumn{2}{|c|}{ Forest }} & \multirow{2}{*}{\multicolumn{2}{|c|}{ Pasture }} & \multicolumn{4}{|c|}{ Cropped } \\
\hline & & & & & \multicolumn{2}{|c|}{$6-9$ years } & \multicolumn{2}{|c|}{$>20$ years } \\
\hline $0-20$ & 57.97 & $\mathrm{a}$ & 32.07 & $\mathrm{~b}$ & 32.54 & $\mathrm{~b}$ & 31.84 & $\mathrm{~b}$ \\
\hline $20-40$ & 19.52 & $\mathrm{a}$ & 20.67 & $\mathrm{a}$ & 18.48 & $\mathrm{a}$ & 19.19 & $\mathrm{a}$ \\
\hline $40-60$ & 18.90 & $\mathrm{a}$ & 18.54 & $\mathrm{a}$ & 11.62 & $\mathrm{~b}$ & 10.83 & b \\
\hline $60-80$ & 15.16 & $\mathrm{a}$ & 11.69 & $\mathrm{~b}$ & 10.15 & $\mathrm{bc}$ & 7.89 & $\mathrm{c}$ \\
\hline $80-100$ & 8.62 & $\mathrm{bc}$ & 11.60 & $\mathrm{a}$ & 9.03 & $\mathrm{~b}$ & 6.74 & $\mathrm{c}$ \\
\hline $0-100$ & 120.17 & $\mathrm{a}$ & 94.57 & $\mathrm{~b}$ & 81.82 & $\mathrm{bc}$ & 76.49 & $\mathrm{c}$ \\
\hline \multicolumn{9}{|c|}{$\mathrm{BD}\left(\mathrm{Mg} \mathrm{m}^{-3}\right)$} \\
\hline \multirow[t]{2}{*}{ Depth $(\mathrm{cm})$} & \multirow{2}{*}{\multicolumn{2}{|c|}{ Forest }} & \multirow{2}{*}{\multicolumn{2}{|c|}{ Pasture }} & \multicolumn{4}{|c|}{ Cropped } \\
\hline & & & & & \multicolumn{2}{|c|}{$6-9$ years } & \multicolumn{2}{|c|}{$>20$ years } \\
\hline $0-20$ & 0.89 & $\mathrm{c}$ & 1.10 & $\mathrm{~b}$ & 1.11 & $\mathrm{~b}$ & 1.21 & $\mathrm{a}$ \\
\hline $20-40$ & 0.96 & $\mathrm{c}$ & 1.09 & $\mathrm{~b}$ & 1.07 & $\mathrm{~b}$ & 1.14 & $\mathrm{a}$ \\
\hline $40-60$ & 1.00 & $\mathrm{~d}$ & 1.17 & $\mathrm{a}$ & 1.07 & c & 1.13 & $\mathrm{~b}$ \\
\hline $60-80$ & 1.08 & $\mathrm{a}$ & 1.11 & $\mathrm{a}$ & 1.10 & $\mathrm{a}$ & 1.09 & $\mathrm{a}$ \\
\hline $80-100$ & 1.14 & $\mathrm{a}$ & 1.15 & $\mathrm{a}$ & 1.15 & $\mathrm{a}$ & 1.16 & $\mathrm{a}$ \\
\hline
\end{tabular}

est had the greatest content, due to its higher net primary productivity, pastures represented the intermediate situation and the lowest contribution corresponded to crops that in this region consist of one summer crop per year (Follet et al., 2009). The most important annual crops in the region are soybean, maize and cotton. Comparing cropped and pristine soils in the Pampean region, Sainz Rozas et al. (2011) found that $\mathrm{SOC}$ reduction for the $0-20 \mathrm{~cm}$ layer ranged between $36 \%$ and $53 \%$, which placed our regional results in the middle of this range of variation. This loss of SOC can be explained by the lower $\mathrm{C}$ input due to harvesting, the greater mineralisation and the greater susceptibility to erosion of these soils (Alvarez, 2001). Land use had different effects on SOC fractions (Fig. 2). At both soil depths, coarse particulate carbon (2000-212 $\mu \mathrm{m}, \mathrm{CPC})$ showed the greatest differ- ences between land uses. Resistant organic carbon $(<53 \mu \mathrm{m}$, $\mathrm{RC}$ ) was the main constituent of soil organic matter in all land uses except in the forest, where CPC was the main fraction, with $65 \%$ of total SOC in the $0-5 \mathrm{~cm}$ layer and $55 \%$ in the $5-20 \mathrm{~cm}$ layer. The $\mathrm{SOC}$ fraction most affected by land use change was the most labile (CPC, 212-200 $\mu \mathrm{m})$, which represented $6 \%$ of total SOC in cropped sites and $57 \%$ in pastures and forest sites. Our results are similar to those of Balesdent et al. (1998), who found that the SOC of soils decreased rapidly in the first 7 years of cultivation and more slowly after, and the decrease affected mostly the coarse CPC fractions. The higher RC content in the cropped sites (78\% of total SOC) showed that there is a shift towards more humified fractions, which have a lower rate of nutrient mineral- 


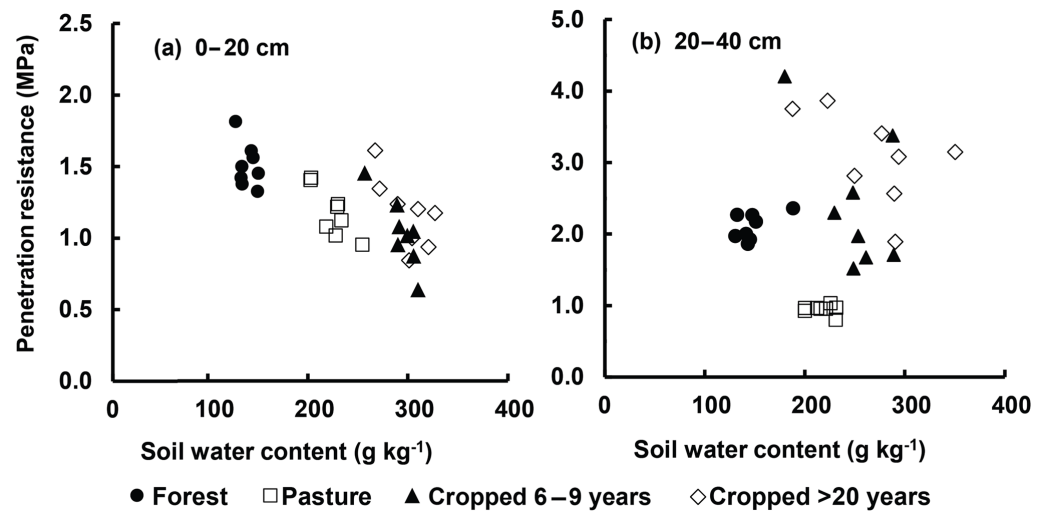

Figure 3. Functional relationships between soil penetration resistance and gravimetric water content for different land uses at two depths (a $0-20 \mathrm{~cm} ; \mathbf{b} 20-40 \mathrm{~cm})$.

isation, results that coincide with those obtained by Albanesi et al. (2003) and Galantini and Suñer (2008).

In soils with native forest, $\mathrm{BD}$ increased with depth, from $0.88 \mathrm{Mg} \mathrm{m}^{-3}$ in the $0-20 \mathrm{~cm}^{2}$ layer to $1.14 \mathrm{Mg} \mathrm{m}^{-3}$ at 80 $100 \mathrm{~cm}$ depth. The cropped fields did not follow this trend. Their BD was highest in the surface layer $(0-20 \mathrm{~cm})$ and in depth $(80-100 \mathrm{~cm})$ and lowest at 20 to $80 \mathrm{~cm}$. The pasture under 15 years of livestock production had similar values to the fields cropped for 6-9 years. These higher surface BD values were a consequence of the decrease in SOC and machinery transit in cropped fields (Alvarez et al., 2012) and of the mechanical pressure exerted by livestock in the pastures (Alvarez et al., 2012). Soils under more than 20 years of cropping had a BD of $1.20 \mathrm{Mg} \mathrm{m}^{-3}$ in the first $20 \mathrm{~cm}$, $8 \%$ higher than soils under 6-9 years cropping or pasture $\left(1.11 \mathrm{Mg} \mathrm{m}^{-3}\right)$ and $36 \%$ higher than the values of the forest soil $\left(0.88 \mathrm{Mg} \mathrm{m}^{-3}\right)$. Finally, soil BD in $0-20 \mathrm{~cm}$ was highly correlated with SOC $(r=-0.9 ; p>0.0001)$ but not with soil particle size fractions.

The highest soil aggregate MWD values were measured in forest $(1.61 \mathrm{~mm})$ and pasture $(1.74 \mathrm{~mm})$ soils, values that were not statistically different. Cropped sites showed an average MWD of $0.76 \mathrm{~mm}$, half that of forest and pasture soils and significantly $(P<0.05)$ different to that of those two land use categories. In all land uses, fast wetting was the treatment that reduced MWD most, reducing the size of aggregates by $40 \%$ when compared with the treatment of less stress (slow wetting by capillarity). MWD, which characterises structural stability, was directly related to CPC $(r=0.6, p=<0.01)$ and to SOC $(r=0.48, p<0.01)$. CPC loss of the first $20 \mathrm{~cm}$ largely explained the loss of MWD in cropped soils. Organic matter influences soil structure, but at the same time the formation of stabilised aggregates facilitates carbon sequestration and provides physical protection to soil carbon (Onweremadu, 2007). In contrast, pastures, despite having a lower amount of coarse particulate carbon $(212-200 \mu \mathrm{m})$ than the forest, had the same MWD values.
This could respond to the presence of a fine root network of the pasture grass (Gatton panic) that improved aggregate resistance to stress.

Penetration resistance $(\mathrm{PR})$ at $0-20 \mathrm{~cm}$ depth showed a negative correlation with SWC $(r=-0.72 ; p<0.0001$; Fig. 3a). PR of cropped fields was $1.1 \mathrm{MPa}$ with $290 \mathrm{~g} \mathrm{~kg}^{-1}$ SWC; pastures had the same PR value at that depth but with lower SWC $\left(220 \mathrm{~g} \mathrm{~kg}^{-1}\right)$. Forest showed higher PR values $(1.5 \mathrm{MPa})$ as at the moment of sampling, SWC was lower $\left(130 \mathrm{~g} \mathrm{~kg}^{-1}\right)$. At a greater depth $(20-40 \mathrm{~cm})$, no correlation was found between those two variables ( $p=0.32$; Fig. $3 b)$. Fields under more than 20 years of cropping had an average PR of $3 \mathrm{MPa}$ with high SWC values $\left(270 \mathrm{~g} \mathrm{~kg}^{-1}\right)$. Soils with 6-9 years continuous cropping and forests had a PR of $2.2 \mathrm{MPa}$, with a SWC of $250 \mathrm{~g} \mathrm{~kg}^{-1}$ and $140 \mathrm{~g} \mathrm{~kg}^{-1}$, respectively. The pasture had the lowest PR (0.9 MPa) with a SWC of $210 \mathrm{~g} \mathrm{~kg}^{-1}$. Below $20 \mathrm{~cm}$ depth, there was soil hardening in cropped sites; even with high SWC values $\left(270 \mathrm{~g} \mathrm{~kg}^{-1}\right)$, their PR values were higher than $2 \mathrm{MPa}$, which could be critical for root development. This would indicate soil compaction due to continuous machinery transit. Values lower than $1.50 \mathrm{MPa}$ at $0-20 \mathrm{~cm}$ depth could be attributed to the high organic matter content at that depth (Table 3 and Fig. 3).

\section{Conclusions}

In the study region, SOC content, its quality and its distribution in the profile were sensitive to the change in land use. The conversion of Chaco forests to crop production was associated with SOC stock reductions up to $1 \mathrm{~m}$ depth and with the decrease of the labile fraction, which mainly occurred in the first years after deforestation. Permanent pastures proved to be a sustainable practice to mitigate $\mathrm{C}$ stock loss compared with cropping systems. It is of great interest to note that carbon losses are not restricted to the first few centimetres of the soil, as is generally shown in organic carbon maps or in greenhouse gas inventories. The development of models that 
would allow the estimation of SOC changes in depth would be useful to evaluate the impact of land use change on carbon stocks with greater precision. We recommend that efforts are increased to minimise or stop deforestation in the South American Chaco, as remaining native forests provide numerous essential ecosystem services such as carbon sequestration, climate and flood regulation and preservation of biodiversity. The change in land use also affected soil physical properties, such as compaction, loss of structural stability in the first $20 \mathrm{~cm}$ and hardening of the $20-40 \mathrm{~cm}$ depth layer in fields under no-till farming. Pastures, despite their lower SOC and CPC contents than the pristine soils, had a structural stability equal to that of the forest, showing that physical properties are not only correlated with the level of carbon in a soil, but also depend on the type of roots of the replacement vegetation and the stresses applied to the soil (i.e. machinery transit).

Data availability. The dataset is available at https://www.dropbox. com/s/i28ac8dl2dx1i3x/Datos.xlsx?dl=0, last access: 29 October 2018 .

Author contributions. NAO, CRÁ and MAT collected samples and wrote and edited the paper. NAO did chemical soil analysis and processed the data. CRÁ and MAT were responsible for the experimental design, funding acquisitions and project administration. NAO was a doctoral student and CRÁ and MAT her advisors.

Competing interests. The authors declare that they have no conflict of interest.

Special issue statement. This article is part of the special issue "Regional perspectives and challenges of soil organic carbon management and monitoring - a special issue from the Global Symposium on Soil Organic Carbon 2017'. It is a result of the Global Symposium on Soil Organic Carbon, Rome, Italy, 21-23 March 2017.

Acknowledgements. This work has been funded by UBACyT project no. 20020130100274BA. Farmers are thanked for their help in carrying out this work on their properties.

Edited by: Viridiana Alcéntara

Reviewed by: Pia Gottschalk

\section{References}

Albanesi, A., Anriquez, A., and Polo Sánchez, A.: Efectos de la agricultura convencional sobre algunas formas del carbono en una toposecuencia de la Región Chaqueña, Argentina, AgriScientia, XX, 9-17, 2003.
Álvarez, C. R., Taboada, M. A., Gutiérrez Boem, F. H., Bono, A., Fernández, P. L., and Prystupa, P.: Topsoil properties as affected by tillage systems in the Rolling Pampa region of Argentina, Soil Sci. Soc. Am. J., 73, 1242-1250, 2009.

Alvarez, C. R., Fernández, P. L., and Taboada, M. A.: Relación de la inestabilidad estructural con el manejo y propiedades de los suelos de la región pampeana, Ci. Suelo, 30, 173-178, 2012.

Alvarez, R.: Estimation of carbon loses by cultivation from soils of the Argentine Pampa using the Century model, Soil Use Manage., 17, 62-66, 2001.

Baccini, A., Goetz, S. J., and Walker, W. S.: Estimated carbon dioxide emissions from tropical deforestation improved by carbondensity maps, Nat. Clim. Change, 2, 182-185, 2012.

Balesdent, J., Besnard, E., Arrouays, D., and Chenu, C.: The dynamics of carbon in particle-size fractions of soil in a forestcultivation sequence, Plant Soil, 201, 49-57, 1998.

Botta, G. F., Joraujuria, D., Balbuena, R., and Rossato, H.: Mechanical and cropping behavior of direct drilled soil under different traffic intensities: effect of soybean (Glycine max L.) yields, Soil Till. Res., 78, 53-58, 2004.

Burke, W., Gabriels, D., and Bouma, J. (Eds.): Soil structure assessment, A. A. Balkema, Rotterdam, the Netherlands, 92 pp., 1986.

Cambardella, C. A. and Elliott, E. T.: Carbon and nitrogen distribution in aggregates from cultivated and native grassland soils, Soil Sci. Soc. Am. J., 57, 1017-1076, 1992.

Caruso, H., Camardelli, M., and Miranda, S.: Efecto del método de desmonte sobre los indicadores de calidad del suelo y la condición de las pasturas en el Chaco Semiárido salteño, AgriScientia, XXIX, 99-105, 2012.

Cerdà, A.: Aggregate stability against water forces under different climates on agriculture land and scrubland in southern Bolivia, Soil Till. Res., 57, 159-166, 2000.

Cerdà, A., Giménez Morera, A., and Bodí Merche, B.: Soil and water losses from new citrus orchards growing on sloped soils in the western Mediterranean basin, Earth Surf Proc. Land., 34, 18221830, https://doi.org/10.1002/esp.1889, 2009.

Derpsch, R., Friedrich, T., Kassam, A., and Li, H. W.: Current status of adoption of no-till farming in the world and some of it main benefits, Int. J. Agric. Biol., 3, 1-25, 2010.

Díaz-Zorita, M., Duarte, G., and Grove, J.: A review of no-till systems and soil management for sustainable crop production in the subhumid and semiarid Pampas of Argentina, Soil Till. Res., 65, 1-18, 2002.

FAO: Global Forest Resources Assessment 2015, FAO Forestry Paper No. 1, UN Food and Agriculture Organization, Rome, 2015.

Follet, R. F., Kimble, J. M., Pruessner, E. G., Samson-Liebig, S., and Waltman, S.: Soil organic carbon stock with depth and land use at various U.S. sites, in: Soil carbon sequestration and the greenhouse effect, edited by: Lal, R., ASACSSA-SSSA, Madison, USA, 29-46, 2009.

Galantini, J. and Suñer, L.: Las fracciones orgánicas del suelo: análisis en los suelos de la Argentina, AgriScientia, 25, 41-55, 2008.

García Orenes, C., Guerrero, C., Roldán, A., Mataix-Solera, J., Cerdá, A., Campoy, M., Zornoza, R., Bárcenas, G., and Caravaca, F.: Soil microbial biomass and activity under different agricultural management systems in a semiarid Mediterranean agroecosystem, Soil Till. Res., 109, 110-115, 2010. 
Gasparri, N. I., Grau, H. R., and Manghi, E.: Desforetation and fragmentation of Chaco dry forest in NW Argentina (1972-2007), Forest Ecol. Manag., 258, 913-921, 2009.

Grau, H. R., Aide, T. M., and Gasparri, N. I.: Globalization and soybean expansion into semiarid ecosystems of Argentina, Ambio, 34, 267-268, 2005.

Hansen, M. C., Potapov, P. V., and Moore, R.: High-resolution global maps of 21st-century forest cover change, Science, 342 , 850-853, 2013.

Harris, N. L., Brown, S., and Hagen, S. C.: Baseline map of carbon emissions from deforestation in tropical regions, Science, 336, 1573-1576, 2012.

Houghton, R. A.: The annual net flux of carbon to the atmosphere from changes in land use 1850-1990, Tellus B, 51, 298-313, 1999.

Jobbágy, E. G. and Jackson, R. B.: The vertical distribution of soil organic carbon and its relation to climate and vegetation, Ecol. Appl., 10, 423-436, 2000.

Le Bissonnais, Y.: Aggregate stability and assessment of soil crustability and erodibility: I. Theory and methodology, Eur. J. Soil Sci., 47, 425-431, 1996.

Neill, C., Melillo, J., Steudler, P. A., Cerri, C. C., Moraes, J. F. L., Piccolo, M. C., and Brito, M.: Soil carbon and nitrogen stocks following forest clearing for pasture in southwestern Brazilian amazon, Ecol. Appl., 7, 1216-1225, 1997.

Nelson, D. W. and Sommers, L. E.: Total carbon, organic carbon, and organic matter, in: Methods of Soil Analysis, Soil Science Society of America, Madison, WI, USA, 961-1010, 1996.
Onweremadu, E. U.: Availability of selected soil nutrients in relation to land use and landscape positions, Int. J. Soil Sci., 2, 128-134, 2007.

Sainz Rozas, H., Echeverria, H. E., and Angelini, H.: Niveles de carbono orgánico y $\mathrm{pH}$ en suelos agrícolas de la región pampeana y extrapampeana argentina, Ci. Suelo, 29, 29-37, 2011.

Satorre, E. H.: Cambios tecnológicos en la agricultura actual. La transformación de la agricultura argentina, Ciencia Hoy, 15, 24 31, 2005.

Strudley, M. W., Green, T. R., and Ascough II, J. C.: Tillage effects on soil hydraulic properties in space and time: state of the science, Soil Till. Res., 99, 4-48, 2008.

Vargas Gil, R.: Chaco sudamericano: regiones naturales, X Reunión Grupo Campos y Chaco FAO UNESCO MAP INTA, 1988.

Volante, J. N., Paruelo, J. M., Vale, L., Morales, C., and Suhring, S.: Dinámica espacial y temporal de la deforestación en la región Chaqueña del Noroeste Argentino Período 1977-2007, Laboratorio de Teledetección y SIG, INTA EEA Salta, Poster. XIII Congreso Forestal Mundial 2009, 2009.

Volante, J. N., Alcaraz-Segura, D., Mosciaro, M. J., Viglizzo, E. F., and Paruelo, J. M.: Ecosystem functional changes associated with land clearing in NW Argentina, Agr. Ecosyst. Environ., 154, 12-22, 2012.

Walker, B. and Steffen, J.: The nature of global changes, in: The terrestrial biosphere and global changes, Cambridge University Press, Cambridge, 1-18, 1999. 